\title{
SOIL ORGANIC MATTER FRACTIONS UNDER SECOND-ROTATION EUCALYPTUS PLANTATIONS IN EASTERN RIO GRANDE DO SUL ${ }^{1}$
}

\author{
Emanuelle Mercês Barros Soares ${ }^{2 *}$, Ivo Ribeiro Silva², Nairam Félix Barros ${ }^{2}$, Rafael Silva Teixeira ${ }^{3}$,
} Sebastião Fonseca ${ }^{4}$, Aline de Almeida Vasconcelos ${ }^{5}$ and Rodrigo Nogueira de Souza ${ }^{6}$

\footnotetext{
${ }^{1}$ Received on 18.12.2013 accepted for publication on 25.10.2016

${ }^{2}$ Universidade Federal de Viçosa, Departamento de Solos, Viçosa, Minas Gerais, Brasil. E-mail: <emanuelle.soares@ufv.br>, <ivosilva@ufv.br>and <nfbarros@ufv.br>.

${ }^{3}$ Universidade Federal de Viçosa, Programa de Pós-Graduação em Solos e Nutrição de plantas, Viçosa, Minas Gerais, Brasil. E-mail: <teixeiramarky@yahoo.com.br>.

${ }^{4}$ Fibria Celulose S.A., Aracruz, Espírito Santo, Brasil.. E-mail: <sf@fibria.com.br>.

${ }^{5}$ Universidade Federal de Viçosa, Doutorado em Solos e Nutrição de plantas, Viçosa, Minas Gerais, Brasil. E-mail: $<$ aa_vasconcelos@yahoo.com.br>.

${ }^{6}$ Universidade Federal de Viçosa, Programa de Pós-Graduação em Solos e Nutrição de plantas, Viçosa, Minas Gerais, Brasil. E-mail:<rodrigoagroufv@gmail.com>.

*Corresponding author.
}

\begin{abstract}
The aim of the present study was to evaluate the effect of eucalyptus plantations on total organic $\mathrm{C}$ (TOC) and total $\mathrm{N}$ (TN) stocks as well as the $\mathrm{C}$ and $\mathrm{N}$ in the fulvic acid (FA), humic acid (HA), humin (HU), light organic matter (LOM) and microbial biomass (MB) fractions in soils with different textures in the eastern part of the state of Rio Grande do Sul, Brazil. Soil samples were collected from the 0-10-cm, $10-20-\mathrm{cm}, 20-40-\mathrm{cm}, 40-60-\mathrm{cm}$ and $60-100-\mathrm{cm}$ soil layers in a completely randomized experimental design with subdivided plots. Under the eucalyptus plantation, clay loam soil presented lower HA, HU and MB C stocks in the $0-100-\mathrm{cm}$ soil layer compared to reference vegetation, whereas sandy soil presented higher and $\mathrm{C}$ and $\mathrm{N}$ in HA and LOM as well as $\mathrm{C}$ in MB. The observed increase in TOC in eucalyptus plantations was more pronounced in the surface soil layer $(0-10 \mathrm{~cm})$, i.e., approximately $150 \%$ higher than under native vegetation, which was probably due to the high contribution of the eucalyptus litter. Differences in $\mathrm{C}$ and $\mathrm{N}$ stocks in soil organic matter (SOM) fractions between eucalyptus plantations and areas with reference vegetation were more pronounced in sandy soil, showing the capacity of the clay fraction to protect SOM.
\end{abstract}

Keywords: Eucalyptus; Microbial biomass; Humic substances.

\section{FRAÇÕES DA MATÉRIA ORGÂNICA EM SOLOS SOB POVOAMENTOS DE EUCALIPTO REFORMADOS NO LESTE DO RIO GRANDE DO SUL}

\begin{abstract}
RESUMO - O objetivo desse trabalho foi avaliar o efeito do cultivo de eucalipto no estoque total de Corgânico (COT) e $N$ total (NT), C e N associados às frações ácido fúlvico (AF), ácido húmico (AH), humina (HU), matéria orgânica leve (MOL) e biomassa microbiana (BM), em solos de diferentes texturas, no Leste do Rio Grande do Sul. O delineamento adotado foi inteiramente casualizado em parcelas subdivididas. As amostras foram coletadas nas camadas de 0-10, 10-20, 20-40, 40-60 e 60-100 cm. Em solo franco-argiloso, a área sob povoamento de eucalipto apresentou redução nos estoques de C associado ao $A H$, $H U$ e BM em relação à vegetação de referência na camada de $0-100 \mathrm{~cm}$. Por outro lado, no solo arenoso houve aumento nos estoques de COT, NT, C e Nassociados à AH, HU, MOL e de C-BM. O aumento no estoque de COTfoi principalmente na camada de superficial $(0-10 \mathrm{~cm})$, aproximadamente $150 \%$ em relação a área de vegetação nativa, provavelmente devido a grande contribuição do resíduo do eucalipto. Ao comparar as áreas com eucalipto e áreas de vegetação de referência, no solo arenoso, nota-se alterações de maior magnitude nos estoques de C e $N$ associados às frações da MOS, o que evidência a capacidade da fração argila em proteger a matéria orgânica do solo.
\end{abstract}

Palavras-chave: Eucalipto; Biomassa microbiana; Substâncias húmicas. 


\section{INTRODUCTION}

Soil organic matter (SOM) is an important indicator of ecosystem sustainability because it is closely related to soil characteristics and processes that directly and indirectly affect the growth of forest species and is an important global $\mathrm{C}$ reservoir. The soil $\mathrm{C}$ sequestration potential of species such as eucalyptus has been previously reported (Livesley et al., 2009; Fest et al., 2009).

Soil organic matter stocks increase due to shoot and root litter input, the protection offered by the soil, climate conditions, the action of decomposing microorganisms and management practices, and soils with higher clay content usually have a higher $\mathrm{C}$ stabilization capacity (Six et al., 2002). Positive correlations have been observed between soil $\mathrm{C}$ and clay and silt+clay contents (Zinn et al., 2005), and because more clayey soils tend to be more highly buffered against variations in SOM than more sandy soils, they are less affected by changes in soil use and management (Zinn et al., 2002).

In addition to the stabilization offered by the soil, the composition of deposited material may contribute to SOM biochemical stabilization (Christensen, 1996). Native forest litter is typically composed of residues whose biochemical properties inhibit decomposition (Khanna et al., 2001), and in eucalyptus plantations in southern Bahia, litter accumulation has similarly been attributed to lower contents of $\mathrm{N}$ and other nutrients in residues as well as higher litter $\mathrm{C} / \mathrm{N}$, lignin/ $\mathrm{N}$ and (lignin + cellulose)/ $\mathrm{N}$ ratios (Gama-Rodrigues and Barros, 2002). The high $\mathrm{C} / \mathrm{N}$ ratio of these residues (between approximately 30 and 100) may result in slower decomposition (Skorupa, 2001), so in eucalyptus plantations, there is a high input of plant residues during the forest rotation and at the time of harvest.

The subsequent re-establishment of eucalyptus plantations following harvest results in additional disturbance due to the preparation for the new plantation, which results in higher $\mathrm{CO}_{2}$ efflux and decreased SOM (Yanai et al., 2003; Chatterjee et al., 2008). These negative effects are minimized by sawlog harvesting (Johnson and Curtis, 2001).

In the present study, soils with different textures from two regions in the eastern part of the state of Rio Grande do Sul, Brazil, were compared to evaluate the effects of eucalyptus plantation establishment in terms of the capacity of the soil mineral matrix to protect SOM. The aim was to compare the total $\mathrm{C}$ and $\mathrm{N}$ stocks in different SOM fractions under eucalyptus plantations and reference vegetation.

\section{MATERIALS AND METHODS}

The study was performed in second-rotation commercial plantations of Eucalyptus grandis in the state of Rio Grande do Sul, where the climate is humid subtropical (Köppen-Geiger climate classification: Cfa). Soil samples were collected from adjacent areas under eucalyptus and native vegetation to perform a paired comparison of the different land uses. Additionally, samples were collected under eucalyptus and native vegetation in two distinct regions presenting different soil textures: sandy and clay loam.

The Barba Negra Forest Plantation (30²4' 5" S latitude and $51^{\circ} 9^{\prime} 56^{\prime \prime} \mathrm{W}$ longitude), which is located in the municipality of Barra do Ribeiro, presents sandy soil that is classified as Quartzarenic Neosol. Eucalyptus plantations were established at this site in April 1987 (first rotation/14-year cycle) and re-established in 2001, and sampling was performed during the second rotation, 4 years after re-establishment. The native vegetation is coastal restinga forest with sparse exuberant plant cover composed of marine-influenced pioneer vegetation (Leite and Klein, 1990).

The Quitéria Forest Plantation $\left(30^{\circ} 00^{\prime} 40^{\prime \prime} \mathrm{S}\right.$ latitude and $51^{\circ} 49^{\prime} 3$ " W longitude), which is located in the municipality of São Jerônimo, presents clay loam soil that is classified as typical Haplic Cambisol. This eucalyptus plantation was established in January 1985 (first rotation/19-year cycle) and re-established in January 2004, and sampling was performed during the second rotation, 1 year after re-establishment. The native vegetation is a grass-shrub steppe with gallery forest (Teixeira et al., 1986).

Following deforestation in both regions, the soils were planted with annual crops and pastures for at least 30 years before the establishment of eucalyptus plantations.

Soil samples were collected from the $0-10-\mathrm{cm}, 10-$ 20-cm, 20-40-cm, 40-60-cm and 60-100-cm soil layers under eucalyptus and native vegetation. A representative 20-30-ha plot of eucalyptus forest and an area of native forest vegetation were selected for sampling. Four replicate 50x50-m plots were defined in each area, and 
5 subsamples were collected in each plot in 2005. The samples were air dried, sieved through a 2-mm mesh and chemically characterized. The clay loam soil presented the following characteristics: $\mathrm{pH}\left(\mathrm{H}_{2} \mathrm{O}\right): 4.50 ; 0.5 \mathrm{cmol}_{\mathrm{c}}$ $\mathrm{dm}^{-3} \mathrm{Ca}^{2+} ; 0.17 \mathrm{cmol}_{\mathrm{c}} \mathrm{dm}^{-3} \mathrm{Mg}^{+2} ; 2.15 \mathrm{cmol}_{\mathrm{c}} \mathrm{dm}^{-3} \mathrm{Al}^{3+}$; $14 \mathrm{cmol}_{\mathrm{c}} \mathrm{dm}^{-3}\left(\mathrm{H}^{+}+\mathrm{Al}^{3+}\right) ; 25 \mathrm{mg} \mathrm{dm}^{-3} \mathrm{P} ; 169.3 \mathrm{mg} \mathrm{dm}^{-3}$ $\mathrm{K}$; and $14.7 \mathrm{cmol}_{\mathrm{c}} \mathrm{dm}^{-3} \mathrm{CEC}_{\mathrm{pH} 7.0}$. The sandy soil presented the following characteristics: $\mathrm{pH}\left(\mathrm{H}_{2} \mathrm{O}\right): 4.14 ; 0.04 \mathrm{cmol}_{\mathrm{c}}$ $\mathrm{dm}^{-3} \mathrm{Ca}^{2+} ; 0.1 \mathrm{cmol}_{\mathrm{c}} \mathrm{dm}^{-3} \mathrm{Mg}^{+2} ; 1.01 \mathrm{cmol}_{\mathrm{c}} \mathrm{dm}^{-3} \mathrm{Al}^{3+}$; $3.15 \mathrm{cmol}_{\mathrm{c}} \mathrm{dm}^{-3}\left(\mathrm{H}^{+}+\mathrm{Al}^{3+}\right) ; 15 \mathrm{mg} \mathrm{dm}^{-3} \mathrm{P} ; 20.2 \mathrm{mg} \mathrm{dm}^{-3}$ $\mathrm{K}$; and $3.3 \mathrm{cmol}_{\mathrm{c}} \mathrm{dm}^{-3} \mathrm{CEC}_{\mathrm{pH} 7.0}$.

In each plot, a $1.2 \mathrm{~m}$-deep trench was excavated for the collection of undeformed soil samples.

Samples of accumulated plant residues were collected from each plot in the eucalyptus plantation and native forest areas with a $0.50-\mathrm{m}^{2}$ quadrat. Following the determination of the total weight of the matter inside the quadrat. Subsamples were collected to determine the soil moisture.

Total organic carbon (TOC) was determined according to Yeomans and Bremner (1988), and total nitrogen (TN) was measured using the Kjeldahl method as modified by Tedesco et al. (1985). Humic substances
(HS) were separated into humic acid (HA), fulvic acid (FA) and humin (HU) by chemical fractionation (SWIFT, 1996), and the free light organic matter (LOM) was determined according to Sohi et al. (2001). Microbial $\mathrm{C}$ and $\mathrm{N}$ biomass (C-MB and $\mathrm{N}-\mathrm{MB}$ ) was determined using the irradiation-extraction method (ISLAM; WEIL, 1998). The $\mathrm{C}$ and $\mathrm{N}$ in all SOM fractions were determined according to Yeomans and Bremner (1988), and total nitrogen (TN) was measured using the Kjeldahl method as modified by Tedesco et al. (1985). For each soil layer, the $\mathrm{C}$ and $\mathrm{N}$ stocks in the SOM fractions were calculated by multiplying the $\mathrm{C}$ and $\mathrm{N}$ concentrations $\left(\mathrm{g} \mathrm{kg}^{-1}\right)$ by the soil weight under the reference vegetation, and the reference soil weight was obtained by multiplying the thickness of each soil layer $(\mathrm{m})$ by its density $\left(\mathrm{kg} \mathrm{dm}^{-3}\right)$ and volume $\left(\mathrm{dm}^{3}\right)$ : soil weight $=($ soil layer thickness in $\mathrm{cm}$ ) $\mathrm{x}\left(\right.$ soil volume in $\left.\mathrm{dm}^{3}\right) \mathrm{x}$ (soil density in $\mathrm{kg} \mathrm{dm}^{3}$ ). The total $\mathrm{C}$ and $\mathrm{N}$ stocks were calculated for the 0-10-cm, 0-20-cm, 0-40-cm, 0-60-cm and 0-100cm soil layers.

The data were subjected to an analysis of variance followed by Fisher's protected LSD test $(\mathrm{p}<0.05)$ (STEEL et al., 1996) assuming a completely randomized experimental design with subdivided plots (soil texture

Table 1 - Textural fractions and density in different layers of sandy soil and clay loam.

Tabela 1 - Frações texturais e densidade nas diferentes camadas do solo arenoso e franco-argiloso.

\begin{tabular}{|c|c|c|c|c|c|}
\hline \multirow[t]{2}{*}{ Horto Florestal } & \multirow{2}{*}{$\begin{array}{c}\text { Soil layer } \\
(\mathrm{cm})\end{array}$} & Coarse sand & Fine sand & Silt & Clay \\
\hline & & \multicolumn{4}{|c|}{ 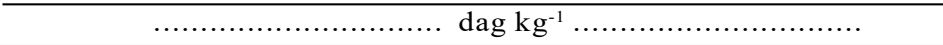 } \\
\hline \multirow{5}{*}{$\begin{array}{c}\text { Barba Negra } \\
\text { Mata }\end{array}$} & $0-10$ & 90 & 4 & 1 & 5 \\
\hline & $10-20$ & 94 & 2 & 2 & 2 \\
\hline & $20-40$ & 94 & 4 & 0 & 2 \\
\hline & $40-60$ & 91 & 7 & 0 & 2 \\
\hline & $60-100$ & 97 & 2 & 0 & 1 \\
\hline \multirow{5}{*}{$\begin{array}{c}\text { Barba Negra } \\
\text { Eucalyptus }\end{array}$} & $0-10$ & 92 & 5 & 1 & 2 \\
\hline & $10-20$ & 94 & 4 & 0 & 2 \\
\hline & $20-40$ & 91 & 7 & 1 & 1 \\
\hline & $40-60$ & 92 & 7 & 0 & 1 \\
\hline & $60-100$ & 91 & 8 & 0 & 1 \\
\hline \multirow{5}{*}{$\begin{array}{l}\text { Quitéria } \\
\text { Mata }\end{array}$} & $0-10$ & 37 & 5 & 12 & 46 \\
\hline & $10-20$ & 27 & 9 & 16 & 48 \\
\hline & $20-40$ & 26 & 1 & 4 & 69 \\
\hline & $40-60$ & 22 & 2 & 10 & 66 \\
\hline & $60-100$ & 24 & 2 & 11 & 63 \\
\hline \multirow{5}{*}{$\begin{array}{l}\text { Quitéria } \\
\text { Eucalyptus }\end{array}$} & $0-10$ & 35 & 7 & 22 & 36 \\
\hline & $10-20$ & 43 & 10 & 13 & 34 \\
\hline & $20-40$ & 35 & 9 & 20 & 36 \\
\hline & $40-60$ & 44 & 9 & 16 & 31 \\
\hline & $60-100$ & 61 & 5 & 11 & 23 \\
\hline
\end{tabular}


in the main plot and soil use in the sub-plots). The data for each soil layer were analyzed separately using SAEG 9.0 software.

\section{RESULTS}

For the clay loam soil, no significant differences were observed in the TOC and TN stocks between eucalyptus plantations and native vegetation $(\mathrm{p}<0.05)$. For sandy soil, soil TOC and TN were significantly higher under eucalyptus plantations than under native vegetation to a depth of $60 \mathrm{~cm}$ for TOC and $20 \mathrm{~cm}$ for $\mathrm{TN}(\mathrm{p}<0.05)$ (Figure 1).

Clay loam soil presented significantly lower $\mathrm{C}$ in the HA (C-HA) and HU (C-HU) fractions in the 0-100$\mathrm{cm}$ soil layer under the eucalyptus plantation than under the native vegetation (Figure 2), but there were no significant differences in N-HA and N-HU (Figure 3). Sandy soil presented higher C-HA and N-HA in the $0-100-\mathrm{cm}$ soil layer under the eucalyptus plantation than under the reference vegetation, and no significant differences were observed in the HU fraction.
For the clay loam soil, no significant differences were observed in the LOM C and N (C-LOM and NLOM, respectively) between the area cultivated with eucalyptus and that with the reference vegetation. For sandy soil, C-LOM was higher under the eucalyptus.

Clay loam soil presented lower microbial biomass $\mathrm{C}$ (C-MB) in the 0-60-cm soil layer under the 1-yearold second rotation eucalyptus plantation than under the reference vegetation. Sandy soil presented higher $\mathrm{C}-\mathrm{MB}$ under the eucalyptus plantation than under the reference vegetation (Figure 4).

Differences in the $\mathrm{C}$ and $\mathrm{N}$ stocks in the SOM fractions between eucalyptus plantations and areas with reference vegetation were more pronounced in sandy soil.

On average, the $\mathrm{C}$ and $\mathrm{N}$ storage capacity in the $0-100-\mathrm{cm}$ clay loam soil layer under native vegetation was 5 times higher than that of the sandy soil. Under the eucalyptus plantation, the TOC in the $0-100-\mathrm{cm}$ soil layer was significantly lower in

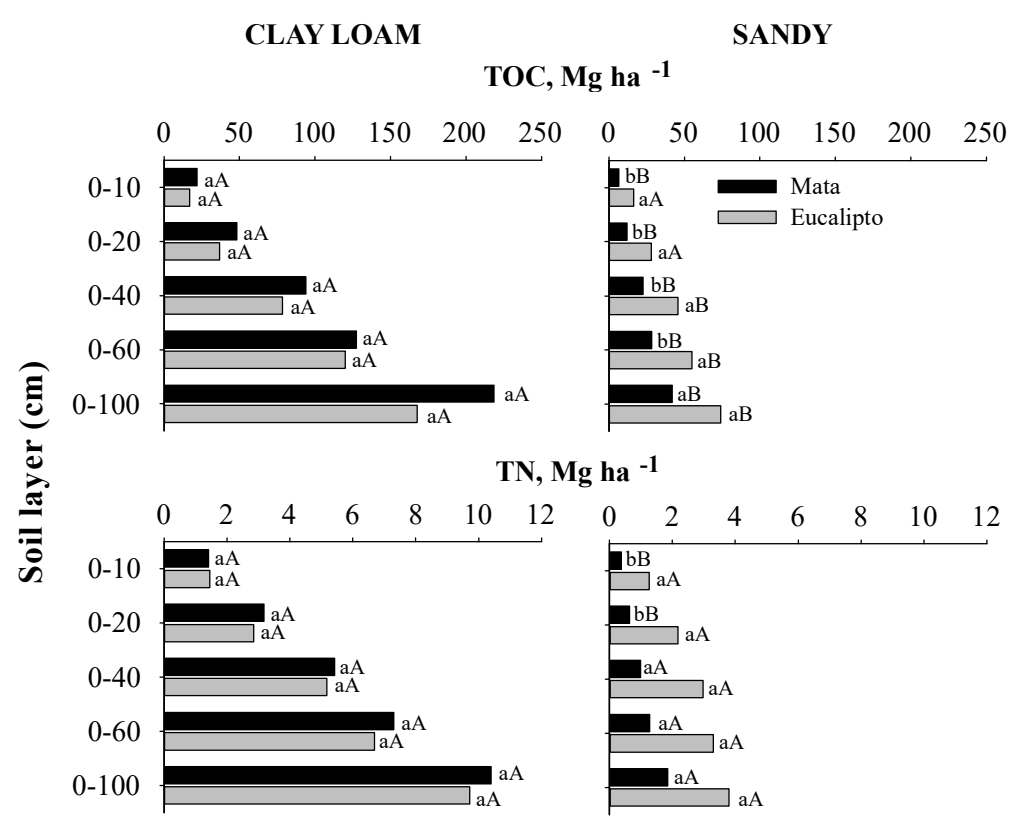

Figure 1 - Total organic C (TOC) and total N (TN) stocks in clay loam and sandy soil under native vegetation or a eucalyptus plantation. Different lower-case letters indicate significant differences between different land uses for each soil layer of each soil type, and different upper-case letters indicate significant differences between soil types for each land use within each soil layer, according to Fisher's protected LSD test, $\mathrm{p} \leq 0.05$.

Figura 1 - Estoques totais de Corgânico (COT) e N (NT) em solo franco-argiloso e arenoso, sob mata nativa e eucalipto. Médias entre os usos do solo, em cada solo, dentro de cada camada, com letras minúsculas iguais não diferem estatisticamente. Médias entre os tipos de solo, para cada uso, dentro de cada camada com letras maiúsculas iguais não diferem estatisticamente. Teste de DMS de Fisher protegido ao nível de $5 \%$. 


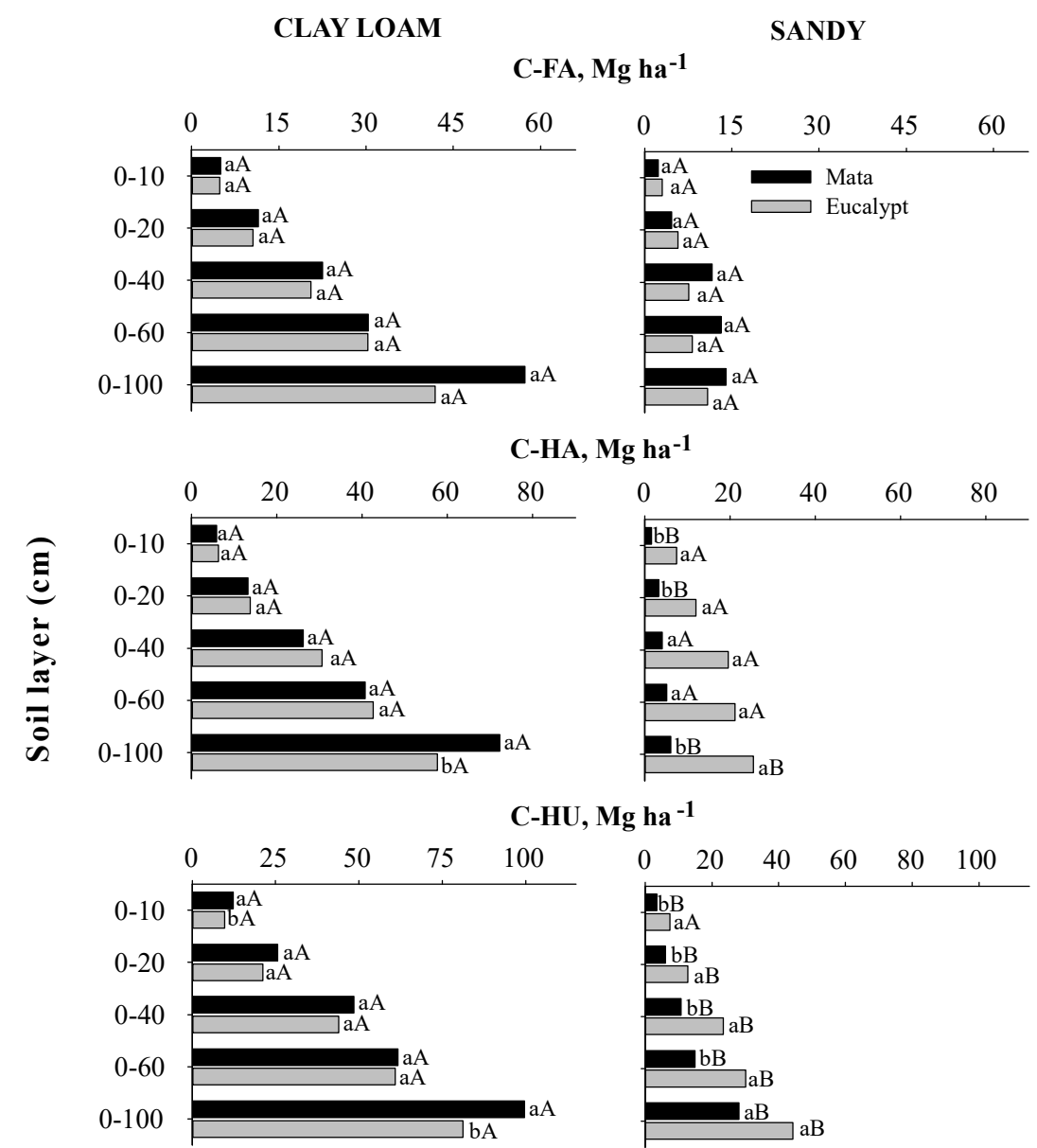

Figure 2 - The C stocks in the fulvic acid (C-FA), humic acid (C-HA) and humin (C-HU) fractions in clay loam and sandy soil under native vegetation or a eucalyptus plantation. Different lower-case letters indicate significant differences between different land uses for each soil type within each soil layer, and different upper-case letters indicate significant differences between soil types for each land use within each soil layer, according to Fisher's protected LSD test, $\mathrm{p} \leq 0.05$.

Figura 2 - Estoques de C associados às frações ácido fúlvico (C-AF), ácido húmico $(C-A H)$ e humina $(C-H U)$ em solo franco-argiloso e arenoso, sob mata nativa e eucalipto. Médias entre os usos do solo, em cada solo, dentro de cada camada, com letras minúsculas iguais não diferem estatisticamente. Médias entre os tipos de solo, para cada uso, dentro de cada camada com letras maiúsculas iguais não diferem estatisticamente. Teste de DMS de Fisher protegido ao nivel de $5 \%$.

the sandy soil $\left(74 \mathrm{Mg} \mathrm{ha}^{-1}\right)$ than the clay loam soil $\left(167 \mathrm{Mg} \mathrm{ha}^{-1}\right)(\mathrm{p}<0.05)$, and C-HA and C-HU were significantly higher in clay loam than sandy soil, under both the eucalyptus plantation and the native vegetation $(\mathrm{p}<0.05$; Figure 2$)$.

In contrast with the TOC and $\mathrm{C}$ in the HS (FA, $\mathrm{HA}$ and HU), the C-LOM in the 0-100-cm soil layer under eucalyptus plantation was higher in sandy soil $\left(9.8 \mathrm{Mg} \mathrm{ha}^{-1}\right)$ than clay loam soil $\left(3.5 \mathrm{Mg} \mathrm{ha}^{-1}\right)$, although the deposition of eucalyptus litter was approximately $20 \%$ higher in clay loam soil (Figure 4 ).

\section{DISCUSSION}

The observed TOC recovery in sandy soil may have been due to the high residue input resulting from high eucalyptus productivity resulting from the favorable climate conditions in the study region of the state of Rio Grande do Sul as well as genetic material 
CLAY LOAM

SANDY

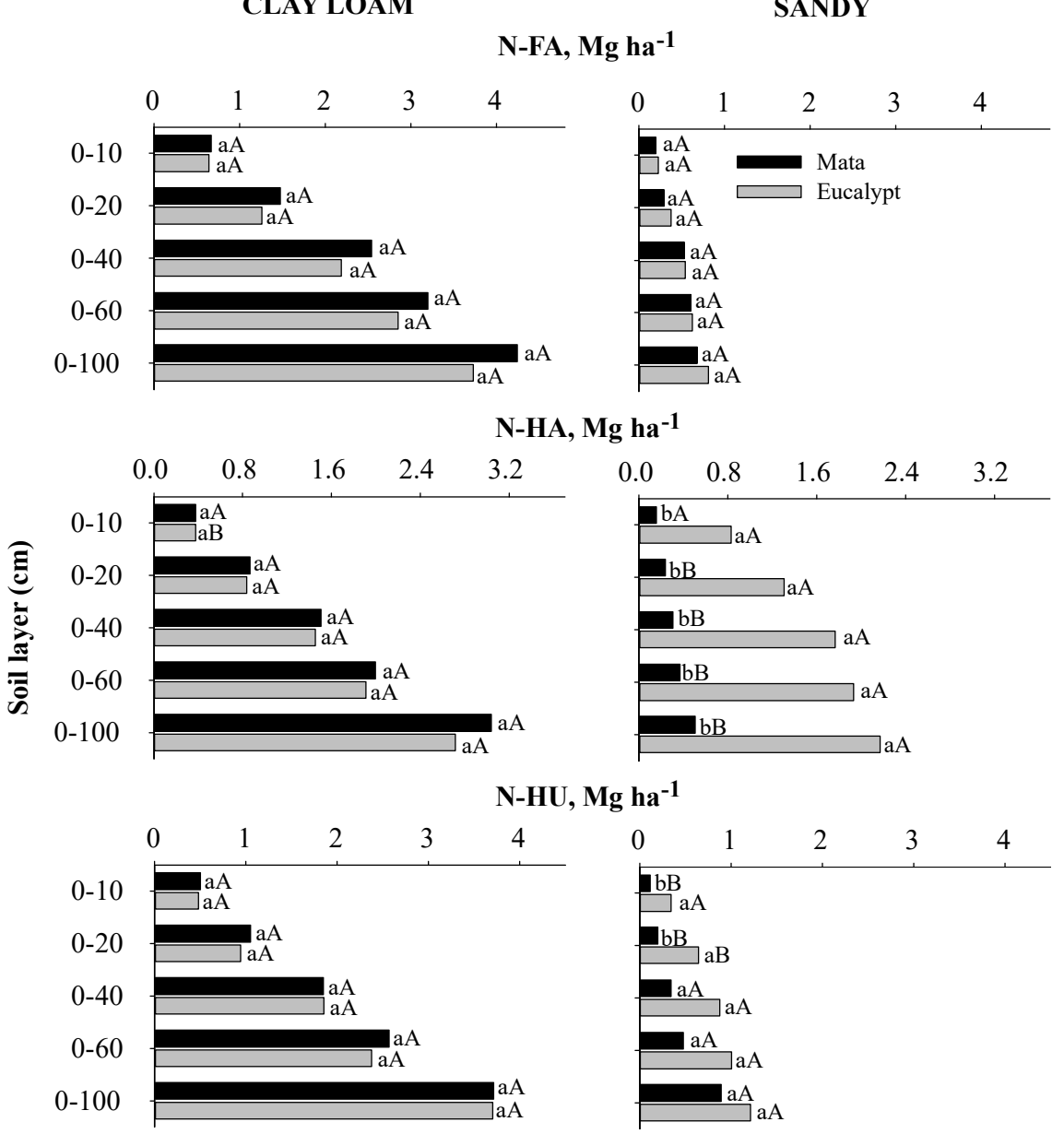

Figure 3 - The N stocks in the humic substances (HS), i.e., the fulvic acid (N-FA), humic acid (N-HA) and humin (NHU) fractions, in clay loam and sandy soils under native vegetation or a eucalyptus plantation. Different lowercase letters indicate significant differences between different land uses for each soil type within each soil layer, and different upper-case letters indicate significant differences between soil types for each land use within each soil layer, according to Fisher's protected LSD test, $\mathrm{p} \leq 0.05$.

Figura 3 - Estoques de $N$ associados às frações das substâncias húmicas, ácido fúlvico ( $N$-AF), ácido húmico $(N-A H) e$ humina ( $N-H U$ ) em solo franco-argiloso e arenoso, sob mata nativa e eucalipto. Médias entre os usos do solo, em cada solo, dentro de cada camada, com letras minúsculas iguais não diferem estatisticamente. Médias entre os tipos de solo, para cada uso, dentro de cada camada com letras maiúsculas iguais não diferem estatisticamente. Teste de DMS de Fisher protegido ao nivel de $5 \%$.

with higher growth potential (E. grandis). Additionally, the higher total $\mathrm{C}$ and $\mathrm{N}$ stocks in sandy soil may have been due to the lower primary productivity of the native vegetation (restinga forest) compared to the eucalyptus plantations, which resulted in lower organic material inputs to the soil. A total $\mathrm{C}$ stock (plant+soil) of $14.15 \mathrm{tha}^{-1}$ year $^{-1}$ was previously reported for an 84-month-old eucalyptus plantation (Gatto et al., 2010).
Considering the total increase in $\mathrm{C}$ in the eucalyptus plantation relative to the reference vegetation and the number of years of eucalyptus cultivation (18 years), the average total soil $\mathrm{C}$ increase rate in the $0-100-\mathrm{cm}$ soil layer was $1.8 \mathrm{Mg} \mathrm{ha}^{-1}$ year-1. $^{-1}$

The observed increases in the $\mathrm{C}$ content of deeper soil layers indicate the root $\mathrm{C}$ input contributions from senescence, turnover and exudation (Rasse et al., 2005). 
a)

CLAY LOAM

SANDY

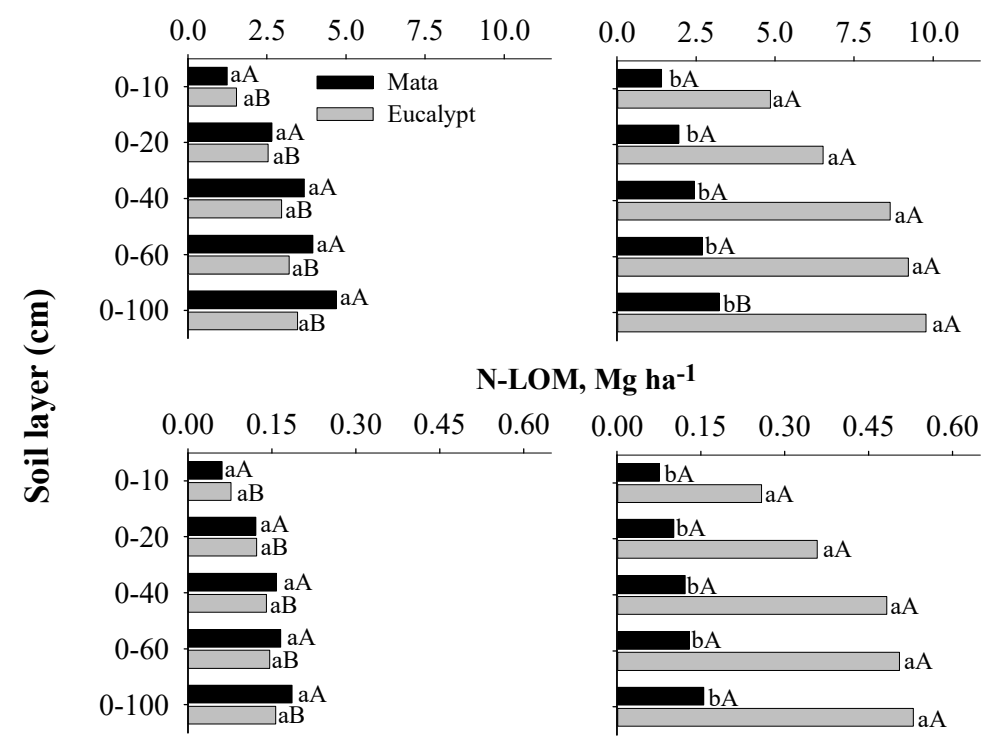

b)

C-MB, Mg ha ${ }^{-1}$

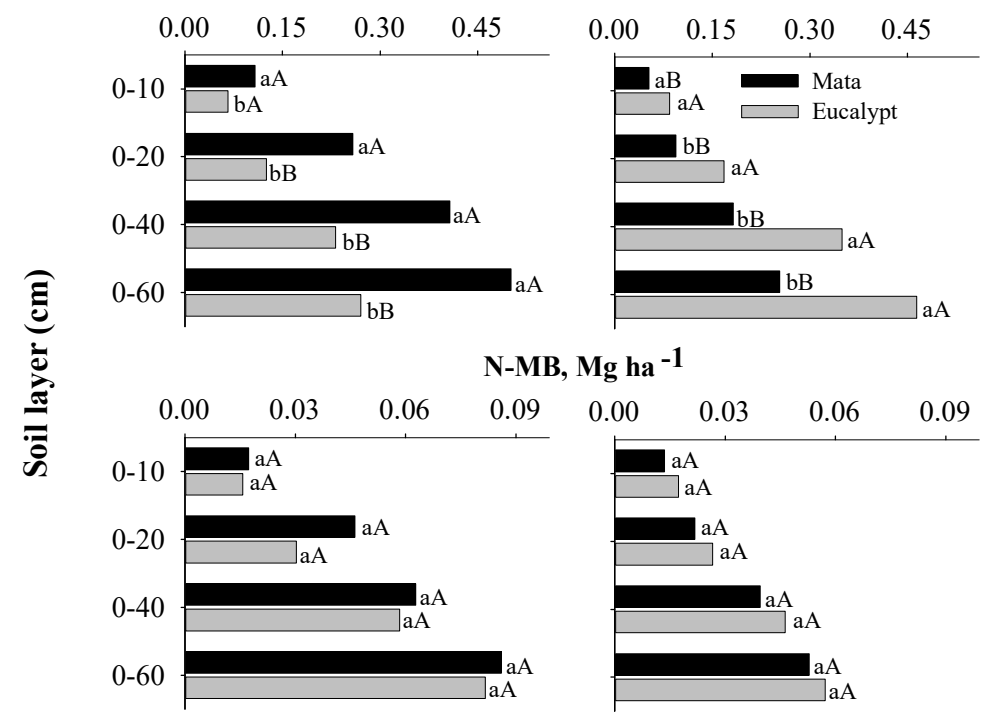

Figure 4 - The a) light organic matter (C-LOM and N-LOM) and b) microbial biomass (C-MB and N-MB) C and N stocks in clay loam and sandy soil under native vegetation or a eucalyptus plantation. Different lower-case letters indicate significant differences between different land uses for each soil type within each soil layer, and different uppercase letters indicate significant differences between soil types for each land use within each soil layer, according to Fisher's protected LSD test, $\mathrm{p}<0.05$.

Figura 4-Estoques de Ce N associado matéria orgânica leve (C-MOL e N-MOL) - a) e associados à biomassa microbiana $(C-B M$ e $N-B M)-b)$, em solo franco-argiloso e arenoso, sob mata nativa e eucalipto. Médias entre os usos do solo, em cada solo, dentro de cada camada, com letras minúsculas iguais não diferem estatisticamente. Médias entre os tipos de solo, para cada uso, dentro de cada camada com letras maiúsculas iguais não diferem estatisticamente. Teste de DMS de Fisher protegido ao nível de $5 \%$. 
A study in the coastal region of the state of Espírito Santo suggested that $\mathrm{C}$ originating from eucalyptus roots from the previous rotation was transferred to SOM over time (Pegoraro et al., 2011). In most plantations, TOC stocks increased until the plantation was three years old, and the average $C$ storage was higher in the $0-60-\mathrm{cm}$ soil layer, which had a higher density of old roots, especially in areas conducted under coppice (Pegoraro et al., 2011).

The lower C-HA and C-HU observed in the clay loam soil under the eucalyptus plantation (Figure 2) likely resulted from the applied forestry practices, especially from disturbances caused by the harvest and the preparations for plantation re-establishment at the end of the first rotation, that disrupted the soil structure and the protection provided by soil aggregates (Devine et al., 2014). In early rotation eucalyptus plantations, such as the clay loam soil in this study (one year after re-establishment), shoot contributions to the litter are low. However, residues originating from the first rotation may contribute to minimizing decreases in $\mathrm{C}$ relative to the original vegetation (Jesus et al., 2015; Epron et al., 2015). Following harvest, $\mathrm{CO}_{2}$ efflux has been shown to increase, and SOM has been shown to decrease (Yanai et al., 2003; Chatterjee et al., 2008), but these negative effects may be minimized by sawlog harvesting (Johnson and Curtis, 2001).

The studied sandy soil was planted with eucalyptus for 18 years with a relatively long period with little anthropic interference during the first rotation (14 years), during which $\mathrm{C}$ deposition via litter and roots may have been high. Mambelli et al. (2011) demonstrated the importance of Pinus leaf and root residue inputs for SOM formation and showed that the selective preservation of plant polymers may be a secondary process of $\mathrm{C}$ and $\mathrm{N}$ stabilization.

The fact that the contribution to the HA and HU fractions was higher in the sandy soil, which has a low potential for physical and colloidal SOM stabilization, may have been due to the contribution of material from the first rotation plantation that had been partially decomposed by the microbial community. In fact, evidence of the direct contribution of partially decomposed and stabilized plant material was observed in A horizon samples from Chernosol soils in temperate regions (Kelleher et al., 2006). Soares et al. (2013) studied sandy soils under eucalyptus plantations in the state of Espírito
Santo using ${ }^{13} \mathrm{C}$ NMR (nuclear magnetic resonance) and observed the contribution of compounds of probable lipid origin to the HA fraction, which may originate from eucalyptus residues and/or microbial activity. This accumulation was observed in all eucalyptus plantations (sandy and clayey soils), when compared to the local native vegetation.

In the sandy soil area, in addition to the deposition of $\mathrm{C}$ from the previous rotation cycle, litter residues had also been deposited into the soil at the time of plantation re-establishment, four years earlier, and during the current rotation, which may have contributed to more pronounced increases in the LOM in the surface soil layers. Light organic matter stocks are frequently regulated by the quantity and quality of the material input to the soil, which are frequently higher in more productive systems (Lima et al., 2008) with organic residue application (Soares et al., 2008), decreased soil inversion, and crop rotation (Bayer et al., 2006). Ashagrie et al. (2005) observed decreased $\mathrm{C}$ and $\mathrm{N}$ stocks in LOM 21 years after the conversion of a Podocarpus-dominated mixed natural forest into a eucalyptus plantation in clayey soil in Ethiopia. In turn, Lima et al. (2006) observed that free LOM was the fraction most sensitive to changes caused by eucalyptus plantations established on degraded pastures.

The SOM storage capacity was higher for the clay loam soil, which probably resulted from higher $\mathrm{C}$ input from plant biomass due to the higher forest production potential and the higher physical and chemical stabilization of SOM due to the higher clay content. Most tropical soils present clay fractions with high oxide contents that play an important role in SOM stabilization (Wiseman and Putmann, 2005; Kleber et al., 2005).

Eucalyptus plantation establishment resulted in more pronounced increases in C-LOM in the 0-100$\mathrm{cm}$ soil layer of sandy soil compared to clay loam. This was likely due to the longer time since plantation reestablishment in sandy soil (four years); i.e., the plantation in sandy soil was in a stage of higher litter deposition. Additionally, the disturbances caused by harvest and re-establishment may have already been reduced. Chaer et al. (2007) observed that the soil quality under a firstrotation eucalyptus plantation ( 11 years) was similar to that of the soil in a reference native forest and that management systems that prioritized organic matter 
conservation and decreased soil inversion during plantation re-establishment also positively affected microbial characteristics.

Santana et al. (2008) summarized eucalyptus shoot production data for different regions in Brazil and found that shoot biomass production varied between $4.7 \mathrm{Mg}$ $\mathrm{ha}^{-1}$ and $9.7 \mathrm{Mg} \mathrm{ha}^{-1}$ in 1-year-old plantations and between $41 \mathrm{Mg} \mathrm{ha}^{-1}$ and $144 \mathrm{Mg} \mathrm{ha}^{-1}$ in 4-year-old plantations. Therefore, C-LOM stocks were in a recovery stage due to higher litter input, which is a $\mathrm{C}$ source for soil microorganisms that resulted in higher MB. Due to its accumulation in more superficial soil layers, C-LOM may be rapidly lost during plantation re-establishment, depending on the forestry practices.

In the sandy soil, eucalyptus residues may have served as a substrate for soil microorganisms. This high $\mathrm{C}$ input in residues may be higher than the decomposition capacity of soil microorganisms, resulting in the accumulation of partially decomposed materials. This has been observed in soils under no tillage crop rotations, which receive high residue input to the soil (Dieckow, 2003) and may explain the higher C-MB stock in the $0-60-\mathrm{cm}$ sandy soil layer $\left(0.46 \mathrm{Mg} \mathrm{ha}^{-1}\right)$ compared to the clay loam soil $\left(0.27 \mathrm{Mg} \mathrm{ha}^{-1}\right)$. Under reference vegetation, C-LOM and C-MB stocks were higher for the clay loam soil. Soil aggregation capacity (Wagner et al., 2007) is one of the main factors regulating the size of the microbial population (Navarro-García et al., 2012).

\section{CONCLUSIONS}

1. In sandy soil, second-rotation eucalyptus plantations four years after re-establishment exhibited higher $\mathrm{C}$ and $\mathrm{N}$ stocks in the $0-100-\mathrm{cm}$ soil layer as well as higher $\mathrm{C}$ in the humic acid, humin, light organic matter and microbial biomass fractions and $\mathrm{N}$ in the humic acid, humin and light organic matter fractions when compared to a resting forest.

2. On clay loam soil, one-year-old second-rotation eucalyptus plantations presented soil $\mathrm{C}$ and $\mathrm{N}$ stocks similar to those of the reference vegetation.

3. The clay loam soil presented a higher $\mathrm{C}$ storage potential.

4. Under eucalyptus plantations, the $\mathrm{C}$ stocks in more labile fractions, such as LOM and MB, were higher in sandy soil.

\section{ACKNOWLEDGEMENTS}

The authors thank the National Council for Scientific and Technological Development (Conselho Nacional de Desenvolvimento Científico e Tecnológico-CNPq) and the Minas Gerais State Research Foundation (Fundação de Amparo à Pesquisa do Estado de Minas Gerais-FAPEMIG) for their continuous financial support, the Fibria forestry company for the use of the experimental area and, especially, the engineer Elias Frank Araújo for assisting with the careful selection of the study sites and the collection of soil samples.

\section{REFERENCES}

Ashagrie Y, Zech W, Guggenberger G. Transformation of a Podocarpus falcatus dominated natural forest into a monoculture Eucalyptus globulus plantation at Munesa, Ethiopia: soil organic $\mathrm{C}, \mathrm{N}$ and $\mathrm{S}$ dynamics in primary particle and aggregate-size fractions. Agriculture, Ecosystems \& Environment. 2005;30(1):89-98.

Bayer C, Martin-Neto L, Mielniczuk J, Pavinato A, Dieckow J. Carbon sequestration in two Brazilian Cerrado soils under no-till. Soil \& Tillage Research. 2006;86(2):237-45.

Chaer GM, Tótola MR. Impacto do manejo de resíduos orgânicos durante a reforma de plantios de eucalipto sobre indicadores de qualidade do solo. Revista Brasileira de Ciência do Solo. 2007;31(6):1381-96.

Chatterjee A, Vance GF, Pendall E, Stahl PD. Timber harvesting alters soil carbon mineralization and microbial community structure in coniferous forests. Soil Biology and Biochemistry. 2008;40(7):1901-7.

Christensen BT. Carbon in primary and secondary organo-mineral complexes. In: Carter MR, Stewart BA, editors. Structure and organic matter storage in agricultural soil. Boca Raton: CRC Press; 1996. p.97-165. (Advances in Soil Science)

Devine S, Markewitz D, Hendrix P, Coleman D. Soil aggregates and associated organic matter under conventional tillage, no-tillage, and forest succession after three decades. PLoS ONE. 2014;9(1):e84988. 
Dieckow, J. Estoque e qualidade da matéria orgânica do solo em função de sistemas de culturas e adubação nitrogenada no sistema plantio direto [tese]. Porto Alegre: Universidade Federal do Rio Grande do Sul; 2003.164p.

Epron D, Mouanda C, Mareschal L, Koutika L-S. Impacts of organic residue management on the soil $\mathrm{C}$ dynamics in a tropical eucalypt plantation on a nutrient-poor sandy soil after three rotations. Soil Biology and Biochemistry. 2015;85:183-9.

Fest BJ, Livesley SJ, Drosler M, Gorsel EV, Arndt SK. Soil-atmosphere greenhouse gas exchange in a cool, temperate Eucalyptus delegatensis forest in south-eastern Australia. Agricultural and Forest Meteorology. 2009;149(3-4):393-406.

Gama-Rodrigues AC, Barros NF. Ciclagem de nutrientes em floresta natural e em plantios de eucalipto e de dandá no sudeste da Bahia, Brasil. Revista Árvore. 2002;26(6):193-207.

Gatto A, Barros NF, Novais RF, Silva IR, Leite HG, Leite FP, et al. Estoques de carbono no solo e na biomassa. Revista Brasileira de Ciência do Solo. 2010;34:1069-79.

Islam KR, Weil RR. Microwave irradiation of soil for routine measurement of microbial biomass carbon. Biology and Fertility of soils. 1998;27:40816.

Jesus GL, Silva IR, Almeida LFJ, Santos MA, Leite FP, Neves JCL. Produtividade do eucalipto, atributos físicos do solo e frações da matéria orgânica influenciadas pela intensidade de tráfego e resíduos de colheita. Revista Brasileira de Ciência do Solo. 201539(4):1190-203.

Johnson DW, Curtis PS. Effects of forest management on soil carbon and nitrogen storage: meta analysis. Foresty Ecology and Management. 2001;140:227-38.

Kelleher BP, Simpson AJ. Humic substances in soils: are they really chemically distinct? Environmental Science \& Technology. 2006;40:4605-11.

Khanna PK, Ludwing B, Bauhus J, O'hara, C. Assessment and significance of labile organic $\mathrm{C}$ pools in forest soils. In: Lal R, Kimble JM, Follet RF, Stewart BA, editors. Assessment methods for soil carbon advances in soil science. Boca Raton: Lewis, 2001.p.167-92.

Kleber M, Miukutta R, Torn S, Jahn R. Poorly crystalline mineral phases protect organic matter in acid subsoil horizons. European Journal of Soil Science. 2005;56:717-25.

Leite P, Klein RM. Vegetação. In: Instituto Brasileiro de Geografia e Estatística. Geografia do Brasil: região Sul. Rio de Janeiro: 1990. p.113-50. v.2.

Lima AMN, Silva IR, Neves JCL, Novais RF, Barros NF, Mendonça ES et al. Soil organic carbon dynamics following afforestation of degraded pastures with eucalyptus in southeastern Brazil. Forest Ecology and Managment. 2006;235:219-31.

Lima AMN, Silva IR, Neves JCL, Novais RF, Barros NF, Mendonça ES et al. Frações da matéria orgânica do solo após três décadas de cultivo de eucalipto no vale do Rio Doce - MG. Revista Brasileira de Ciência do Solo. 2008;32:1053-63.

Livesley SJ, Kiese R, Miehle P, Weston CJ, Butterbach-Bahl K, Aendt SK. Soil-atmosphere exchange of greenhouse gases in a Eucalyptus marginata woodland, a clover-grass pasture, and Pinus radiata and Eucalyptus globulus plantations. Global Change Biology. 2009;15:42540.

Mambelli S, Bird JA, Gleixner G, Dawson TE, Torn ST. Relative contribution of foliar and fine root pine litter to the molecular composition of soil organic matter after in situ degradation. Organic Geochemistry. 2011;42:1099-108.

Navarro-García F, Casemeiro MA, Schimel JP. When structure means conservation: Effect of aggregate structure in controlling microbial responses to rewetting events. Soil Biology and Biochemistry. 2012;44(1):1-8.

Pegoraro RF, Silva IR, Novais RF, Barros NF, Fonseca S, Dambroz CS. Estoques de Carbono e Nitrogênio nas frações da matéria orgânica em Argissolo sob eucalipto e pastagem. Ciência Florestal. 2011;21:261-73. 
Rasse DP, Rumpel C, Dignac MF. Is soil carbon mostly root carbon? Mechanisms for a specific stabilization. Plant Soil. 2005;269:341-56.

Santana RC, Barros NF, Leite HG, Comerford NB, Novais RF. Estimativa de biomassa de plantios de eucalipto no Brasil. Revista Árvore. 2008;32:697706.

Soares EMB, Silva IR, Novais RF, Hu Y, SchimidtRohr K. Alterations in molecular composition of humic substances from eucalypt plantation soils assessed by C-NMR spectroscopy. Soil Science Society of America Journal. 2013;77:293.

Six J, Conant RT, Paul EA, Paustian K.

Stabilization mechanisms of soil organic matter: Implications for C-saturation of soils. Plant Soil. 2002;24:155-76.

Skorupa ALA. Acumulação e decomposição de serapilheira em povoamento de eucalipto na região do Baixo Rio do Doce-MG [tese]. Viçosa, MG: Universidade Federal de Viçosa; 2001. 64p.

Soares BEM, Silva CA, Dias BO, Bettiol W, Belizário $\mathrm{MH}$. Frações da matéria orgânica de Latossolo sob influência de doses de lodo de esgoto. Pesquisas Agropecuária Brasileira. 2008;43:1231-40.

Sohi SP, Mahieu N, Arah JRM, Powlson DS, Madari B, Gaunt JL. A procedure for isolating soil organic matter fractions suitable for modeling. Soil Science Society of America Journal. 2001;65:1121-8.

Steel RGD, Torrie JH, Dickey DA. Principles and procedures of statistics: a biometrical approach. New York: Mc Graw-Hill; 1996. 666p.

Swift RS. Method for extraction of IHSS soil fulvic and humic acids. In: Sparks DL, Page AL, Helmke PA, Loeppert RH, Soltanpour PN,
Tabatabai MA et al. editors. Methods of soil analysis: Chemical methods. Madison: Soil Science Society of America; 1996. Part 3. p.1018-20.

Tedesco HJ, Volkweiss SJ, Bohnen H. Análises de solo, plantas e outros materiais. Porto Alegre: Universidade Federal do Rio Grande do Sul; 1985. 50p. (Boletim técnico, 5)

Teixeira MB, Coura Neto AB, Pastore U, Rangel Filho ALR. Vegetação. In: Instituto Brasileiro de Geografia e Estatística. Levantamento dos recursos naturais. Rio de Janeiro: 1986. v.33. p.541-632.

Wagner S, Cattle SR, Scholten T. Soil-aggregate formation as influenced by clay content and organic-matter amendment. Journal of Plant Nutrition and Soil Science. 2007;170:173-80.

Wiseman CLS, Puttmann W. Interactions between mineral phases in the preservation of soil organic matter. Geoderma. 2005;134:109-18.

Yanai RD, Currie WS, Goodale CL. Soil carbon dynamics after forest harvest: An ecosystem paradigm reconsidered. Ecosystems. 2003;6:197-212.

Yeomans JC, Bremner JM. A rapid and precise method for routine determination of organic carbon in soil. Communications in Soil Science and Plant Analysis. 1988;19:1467-76.

Zinn YL, Lal R, Resck DVS. Changes in soil organic carbon stocks under agriculture in Brazil. Soil \& Tillage Research. 2005;84(1):28-40.

Zinn YL, Resck DVS, Silva JE. Soil organic carbon as affected by afforestation with Eucalyptus and Pinus in the Cerrado region of Brazil. Forest Ecology and Management. 2002;166:285-94. 